\title{
TRANSBOUNDARY VIRTUAL WATER AND WATER FOOTPRINT FOR SOME CROPS IN EGYPT
}

\author{
Khalil, A. A. ${ }^{(1)}$, M. M. Ibrahim ${ }^{(2)}$, M. H. Ramadan ${ }^{(3)}$ \\ ABSTRACT
}

Water footprint and virtual water flow analyses were conducted for rice, wheat, maize, and sugarcane. From results, the water footprint of Egyptian rice is $1593 \mathrm{~m}^{3} /$ ton which is $0 \%$ green, $82 \%$ blue, and $18 \%$ grey water footprint. It is advised to decrease the planted rice area to 0.95 MFed/year. Rice is preferred to import. However, the water footprint of wheat is $1932 \mathrm{~m}^{3} /$ ton which is $2.7 \%$ green, $67.9 \%$ blue, and $29.4 \%$ grey water footprint. It is advised to increase the planted wheat area to $36.7 \mathrm{MFe}$ /year. Wheat is preferred to cover nation consumption and not preferred to import. Not only that but also, the water footprint of Egyptian maize is $2079.8 \mathrm{~m}^{3} /$ ton which is $1 \%$ green, $60.6 \%$ blue, and $38.4 \%$ grey water footprint. It is advised to export maize to get high income. The water footprint of sugarcane is $349.8 \mathrm{~m}^{3} /$ ton which is $0.83 \%$ green, $89.14 \%$ blue, and $10 \%$ grey water footprint. It is advised not to import sugarcane due to the imported is lower than the exported economic water productivity.

Key words: water footprint, green water footprint, blue water footprint, virtual water, economic water productivity, energetic water productivity.

\section{INTRODUCTION}

Water is the source of life on the earth. Difficult to purify, expensive to transport and impossible to substitute, water is essential to: food production, economic development, and to life itself. In the last century, there is a large global water shortage not only because of the physical water scarcity, but also because of poor water management.

By linking a large range of sectors and issues, virtual water and water footprint analyses provide an appropriate framework to find potential solutions and contribute to a better management of water resources (Aldaya and Llamas, 2008). Moreover it is a must to manipulate water use strategy.

\footnotetext{
${ }^{1}$ Agric. Engineer, Agric. Eng. Res. Institute (AERI) - El-Dokki, Cairo.

2 and 3 Assistant Prof. and Prof. of Agric. Eng. Dept., Faculty of Agric., Al-Mansoura Univ.
} 
The concept of water footprint helps to improve policy implications on agriculture geographical dispersion, consumption behavior changes, trade structure adjustment and water use efficiency improvement.

The water footprint is a multidimensional indicator, showing water consumption volumes by source and polluted volumes by type of pollution; all components of a total water footprint are specified geographically and temporally (Hoekstra et al., 2011).

Detailed national water footprint studies have been conducted for European countries (Van Oel $\boldsymbol{e t}$ al., 2009) and countries outside Europe, (Bulsink et al., 2010; Liu and Savenije, 2008; Verma et al., 2009).

In this study, Egypt will be taken as study case. However Egypt is the gift of the Nile, there is shortage in water level because of increasing population and non efficient water use. So a general overview of the virtual water and water footprint will be considered.

The objectives of this study are to quantify the volumes of all virtual water trade flows over the period 2008-2012 in Egypt for some crops from hydrological and economic perspectives and put the virtual water trade balances of these crops within the context of national water needs and water availability.

\section{METHODOLOGY}

The virtual water and water footprint are calculated using the methodology developed by Hoekstra and Hung (2002; 2005) and Chapagain and Hoekstra (2003; 2004).

\section{Crop water requirement estimation:}

For calculating green and blue crop water requirement, evapotranspiration must be estimated. CROPWAT.8 Model was used to estimate green and blue evapotranspiration. There are two different ways to do this: using the crop water requirement option (assuming optimal conditions) or the irrigation schedule option (including the possibility to specify actual irrigation supply in time). The latter option was applied in this study. A comprehensive manual for the practical use of the program is available online (FAO, 2010b). The green and blue components in crop water use (CWU, $\mathrm{m}^{3} / \mathrm{ha}$ ) were calculated by accumulation of daily evapotranspiration (ET, mm/day) over the complete growing period (Hoekstra et al., 2011) as indicated in equations (1) and (2) as follows: 
$\mathrm{CWU}_{\text {green }}\left(\mathrm{m}^{3} / \mathrm{ha}\right)=10 \sum_{\mathrm{d}=1}^{1 \mathrm{gp}} \mathrm{ET}_{\text {green }}$

$\operatorname{CWU}_{\text {blue }}\left(\mathrm{m}^{3} / \mathrm{ha}\right)=10 \sum_{\mathrm{d}=1}^{1 \mathrm{gp}} \operatorname{ET}_{\text {blue }}$

Where

$\mathrm{CWU}=$ crop water requirements (either green or blue) in $\mathrm{m}^{3} / \mathrm{ha}$; and

ET =daily evapotranspiration (either green or blue) in $\mathrm{mm}$.

\section{The water footprint accounting}

Water footprint includes three elements: consumptive use of rain water bounded in the soil (green water); consumptive use of water withdrawn from groundwater or surface water (blue water) and pollution of water (grey water), associates with the production of goods and services (Cong and Stephen, 2009).

The green, blue, and grey water footprints are calculated as follows:

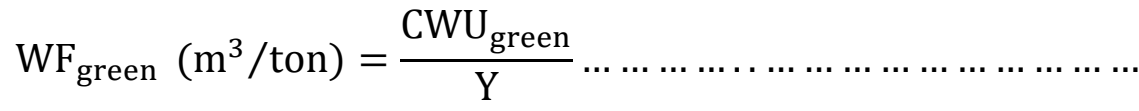

$\mathrm{WF}_{\text {blue }}\left(\mathrm{m}^{3} /\right.$ ton $)=\frac{\mathrm{CWU}_{\text {blue }}}{\mathrm{Y}}$

$\mathrm{WF}_{\text {grey }}\left(\mathrm{m}^{3} /\right.$ ton $)=\left[\frac{\propto * \text { Appl }}{\mathrm{c}_{\max }-\mathrm{c}_{\text {nat }}}\right] / \mathrm{Y}$

$\mathrm{WF}_{\text {Tot }}\left(m^{3} /\right.$ ton $)=W F_{\text {green }}+W F_{\text {blue }}+W F_{\text {grey }}$

Where:

$\mathrm{WF}_{\text {green }}=$ The green water footprint in $\left(\mathrm{m}^{3} / \mathrm{ton}\right)$;

$\mathrm{WF}_{\text {blue }}=$ The blue water footprint in $\left(\mathrm{m}^{3} /\right.$ ton $)$;

$\mathrm{WF}_{\text {grey }}=$ The grey water footprint in $\left(\mathrm{m}^{3} / \mathrm{ton}\right)$;

$\mathrm{WF}_{\text {Tot }}=$ The total water footprint in $\left(\mathrm{m}^{3} /\right.$ ton $)$;

Appl = The chemical application rate to the field per hectare in $(\mathrm{kg} / \mathrm{ha})$;

$\alpha \quad=$ Times the leaching-run-off fraction;

$\mathrm{c}_{\max }=$ The maximum acceptable concentration in $\left(\mathrm{kg} / \mathrm{m}^{3}\right)$;

$\mathrm{c}_{\text {nat }} \quad=$ The natural concentration for the pollutant considered; Nitrogen in $\left(\mathrm{kg} / \mathrm{m}^{3}\right)$; and

$\mathrm{Y}=$ The crop yield in (ton/ha).

\section{Water footprint of a product}


The water footprint of a product concludes the embedded and removed water to the crop during the production. The water footprint of a product is calculated as the total water footprint of non processing crop divided by the product fraction.

$W F_{\text {prod }}\left(m^{3} /\right.$ ton $)=\frac{W F_{\text {tot }}}{F_{\text {prod }}}$

Where:

$\mathrm{WF}_{\text {prod }}=$ The water footprint of a product in $\left(\mathrm{m}^{3} / \mathrm{ha}\right)$; and

$\mathrm{F}_{\text {prod }}=$ The product fraction.

Product fractions can best be taken from the literature available for a specific production process (FAO, 2003).

Energetic water productivity (G.W.P)

Since the amount of energy produced by the unit mass of a crop fixed, the static indicator of the energy water productivity consumed or transported across different products for different countries. The energetic water productivity may be calculated as follows:

G.W.P $=\frac{\mathrm{En}_{\text {output }}}{W F_{\text {Tot }}}$

Where:

G.W.P = Energetic water productivity in $\left(\mathrm{Kcal} / \mathrm{m}^{3}\right)$; and

$\mathrm{En}_{\text {output }}=$ Energy output of the crop in $(\mathrm{Kcal} / \mathrm{ton})$ from Pimentel and Hall (1984) as follows:

\begin{tabular}{c|c}
\hline Crops & Energy output (Kcal/ton) \\
\hline Rice & 3799233.182 \\
Wheat & 3313550.94 \\
Maize & 3500000 \\
Sugarcane & 379771.5 \\
\hline
\end{tabular}

Economic water productivity (C.W.P)

The water economic productivity analysis can be very useful in order to identify possible water uses not justified in economic efficiency terms and achieve an efficient allocation of water resources (Aldaya and Llamas, 2008). Water economic productivity is calculated as follows:

C. W.P $=\frac{G \cdot W \cdot P}{p_{E N}}$

Where: 
G.W.P $=$ The energetic water productivity in $\left(\mathrm{Kcal} / \mathrm{m}^{3}\right)$; and

$\mathrm{P}_{\mathrm{EN}}=$ Energy price in $(\$ / \mathrm{Kcal})$ from source (World Bank, 2015).

Virtual water trade flows and the national virtual water trade balance

Step 1: The volume of virtual water imported into Egypt $\left(\mathrm{m}^{3} / \mathrm{yr}\right)$ is calculated as follows:

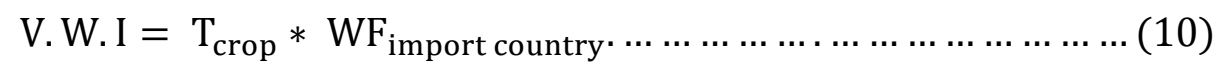

Where:

V.W.I = Virtual water imported $\left(\mathrm{m}^{3} /\right.$ year $)$;

$\mathrm{T}_{\text {crop }}=$ Crop trade (ton/year); and

$\mathrm{WF}_{\text {import country }}=$ The virtual water content $\left(\mathrm{m}^{3} /\right.$ ton $)$.

Step 2: The volume of virtual water exported from Egypt $\left(\mathrm{m}^{3} /\right.$ year) is calculated as:

V.W.X $=\mathrm{T}_{\text {crop }} * \mathrm{WF}_{\text {Egypt }}$

Where:

V.W.X $=$ Virtual water exported $\left(\mathrm{m}^{3} /\right.$ year $)$;

$\mathrm{WF}_{\text {Egypt }}=$ The export quantity by the average virtual water content of the crop $\left(\mathrm{m}^{3} /\right.$ ton $)$; and

$\mathrm{T}_{\text {crop }}=$ The amount of the crop exported (ton/year).

Step 3: The net virtual water import is calculated by subtracting the total virtual water import from the total virtual water export.

\section{RESULTS AND DISCUSSION}

The water footprint and virtual water flow analyses for rice, maize, wheat, and sugarcane crops are evaluated over the period (2008-2012). For these analyses, Egypt has been divided and analyzed into four areas (Upper, Middle, Lower Egypt and New areas).

\section{Rice crop}

\section{1- Cropping area}

The total planted area of rice in Egypt is about $1.47 \mathrm{M}$ Fed. As a whole, more than $99 \%$ of the crop area is planted in Lower Egypt. As well as, Middle Egypt planted about $0.47 \%$ of total area. On the other side, New Areas planted about $0.26 \%$ of the total area. The total planted area of rice over the period (2008-2012) is shown in Table (1). 
Table 1: The total planted area (Feddan) of rice over the period (2008-2012)

\begin{tabular}{l|ccccc|c}
\hline Egyptian & \multicolumn{5}{|c|}{ Years } & \multirow{2}{*}{ Average } \\
\cline { 2 - 6 } Regions & 2008 & 2009 & 2010 & 2011 & 2012 & \\
\hline Lower & 1729363 & 1368608 & 1378550 & 1404937 & 1399504 & 1456192 \\
Middle & 31941 & 484 & 101 & 285 & 1431 & 6848.4 \\
NewAreas & 8478 & 146 & 2091 & 3935 & 4282 & 3786.4 \\
\hline Total & 1769782 & 1369238 & 1380742 & 1409157 & 1405217 & 1466827 \\
\hline
\end{tabular}

\section{1- Total water footprint for rice}

The water footprint analysis establishes the amount of water required by specific crops and it differs considerably among crop type, yield and climate. Figure (1) provides an overview of the water footprint of rice $\left(\mathrm{m}^{3} /\right.$ ton $)$ in the different sections of the Egypt over different years. As shown in this figure, it is noteworthy that, New Areas containing larger amounts of water footprint (about $2246 \mathrm{~m}^{3} /$ ton) and Middle Egypt (about $1918 \mathrm{~m}^{3} /$ ton), however, Lower Egypt containing smaller amounts of water footprint (about $1435.9 \mathrm{~m}^{3} /$ ton) with regarded to Chapagain and Hoekstra (2010). This result may be explained by the differences in yield, climate, and soil type for each region.

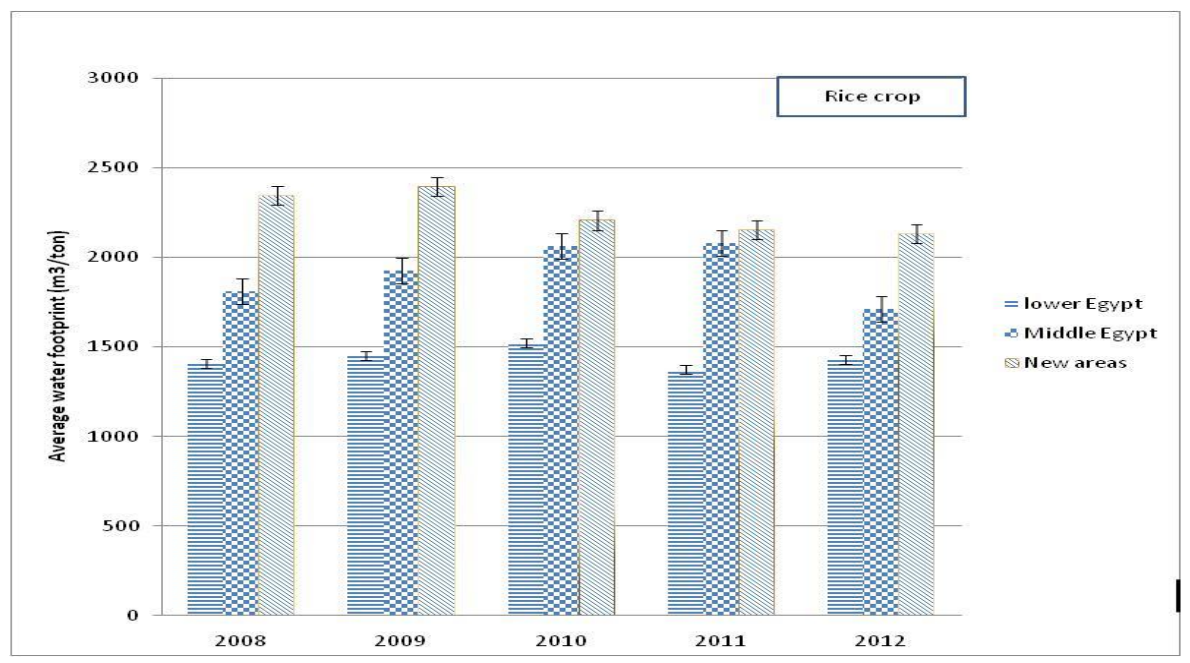

Fig. 1 Total water footprint of rice over the period (2008-2012)

The soil type in Lower Egypt is black and salty soil however Middle Egypt and New areas are medium black and sandy soil. In Lower Egypt, rice yield is about 8.9 ton/ha however yield in Middle Egypt and New Areas are 8.3 and 6.9 ton/ha respectively. 
Table 2: Means, Standard deviation and Duncan's Multiple Range Test for total water footprint in different regions over the period (2008-2012).

\begin{tabular}{c|cc|cc|cc}
\hline \multirow{2}{*}{ Years } & \multicolumn{6}{|c}{ Egyptian regions } \\
\cline { 2 - 7 } & \multicolumn{2}{|c|}{ Lower } & \multicolumn{2}{c}{ middle } & \multicolumn{2}{c}{ New areas } \\
\cline { 2 - 7 } & Means & SD & Means & SD & Means & SD \\
\hline 2008 & $1409^{\mathrm{N}}$ & 224 & $1812^{\mathrm{N}}$ & 292 & $2344^{*}$ & 514 \\
2009 & $1452^{\mathrm{N}}$ & 261 & $1926^{\mathrm{N}^{*}}$ & 43 & $2394^{*}$ & 379 \\
2010 & $1520^{\mathrm{N}}$ & 378 & $2063^{\mathrm{N}}$ & - & $2205^{\mathrm{N}}$ & 456 \\
2011 & $1371^{\mathrm{N}}$ & 249 & $2080^{*}$ & - & $2155^{*}$ & 88 \\
2012 & $1429^{\mathrm{N}}$ & 261 & $1712^{\mathrm{N}^{*}}$ & 270 & $2199^{*}$ & - \\
\hline
\end{tabular}

$*$ and $\mathrm{N}$ having the same letter in each column are not significantly at $\mathrm{p}_{\mathrm{r}}<0.05$. The slash (-) means that there is not stander division for this region because there is one governorate planted rice there.

Table 3: Internal water footprint of produced rice $\left(\mathrm{m}^{3} / \mathrm{ton}\right)$ for each region in Egypt over the period (2008-2012).

\begin{tabular}{|c|c|c|c|c|c|}
\hline \multirow{2}{*}{ Region } & \multicolumn{3}{|c|}{$\begin{array}{c}\text { Water footprint } \\
\left(\mathrm{m}^{3} / \text { ton }\right)\end{array}$} & \multirow{2}{*}{$\begin{array}{c}\text { Economic } \\
\text { water } \\
\text { productiv- } \\
\text { ity } \\
\left(\$ / \mathrm{m}^{3}\right)\end{array}$} & \multirow{2}{*}{$\begin{array}{c}\text { Energetic } \\
\text { water } \\
\text { productivit } \\
\mathrm{y} \\
\left(\mathrm{Kcal} / \mathrm{m}^{3}\right)\end{array}$} \\
\hline & Green & Blue & Grey & & \\
\hline \multicolumn{6}{|c|}{2008} \\
\hline lower Egypt & 0.09 & 1120.25 & 288.25 & 3.0 & 2821.98 \\
\hline middle Egypt & 0.07 & 1514.42 & 297.02 & 2.2 & 2137.30 \\
\hline New areas & 0 & 1919.25 & 425.11 & 1.7 & 1660.61 \\
\hline \multicolumn{6}{|c|}{2009} \\
\hline lower Egypt & 0.17 & 1151.38 & 300.04 & 3.0 & 2693.85 \\
\hline middle Egypt & 0 & 1621.61 & 303.97 & 2.2 & 1973.53 \\
\hline New areas & 0 & 1987.45 & 407.01 & 1.8 & 1606.83 \\
\hline \multicolumn{6}{|c|}{2010} \\
\hline lower Egypt & 19.89 & 1192.06 & 307.66 & 3.0 & 2629.56 \\
\hline middle Egypt & 0 & 1761.26 & 301.36 & 2.1 & 1841.95 \\
\hline New areas & 1.61 & 1827.17 & 376.03 & 2.0 & 1760.82 \\
\hline \multicolumn{6}{|c|}{2011} \\
\hline lower Egypt & 2.31 & 1079.25 & 289.61 & 3.1 & 2849.12 \\
\hline middle Egypt & 0 & 1756.38 & 323.54 & 2.0 & 1826.62 \\
\hline New areas & 0.24 & 1754.09 & 400.38 & 1.9 & 1764.71 \\
\hline \multicolumn{6}{|c|}{2012} \\
\hline lower Egypt & 19.27 & 1121.80 & 287.58 & 3.0 & 2741.84 \\
\hline middle Egypt & 26.09 & 1410.97 & 275.21 & 2.5 & 2246.83 \\
\hline New areas & 0 & 1746.69 & 386.22 & 2.0 & 1783.00 \\
\hline
\end{tabular}

\section{2- Energetic water productivity $\left(\mathrm{Kcal} / \mathrm{m}^{3}\right)$}


The average water energetic productivity for Egypt is about 2155.9 $\mathrm{Kcal} / \mathrm{m}^{3}$. Concerning the energetic water productivity per region, Lower Egypt has the highest revenues per one cubic meter of water (about 2747 $\mathrm{Kcal} / \mathrm{m}^{3}$ ), followed by Middle Egypt (about $2005.4 \mathrm{Kcal} / \mathrm{m}^{3}$ ), New Areas have productivities of water less than $1715 \mathrm{Kcal} / \mathrm{m}^{3}$. The highest water footprint is the lowest energetic water productivity because of this productivity is depending on water footprint. So the highest energetic water productivity region is where preferred planting rice in Lower Egypt.

\section{3- Economic water productivity $\left(\$ / \mathbf{m}^{3}\right)$}

The average water economic productivity for Egypt is about $2.5 \$ / \mathrm{m}^{3}$. As given in Table 3 Lower Egypt has the highest economic water productivity so rice should be planted in it to get high income. As well as, New Areas have the lowest economic water productivity so rice should not be planted in it. High economic productivity means high income from low water footprint.

\section{4- Virtual water trade flows and the national virtual water trade balance}

The net virtual water export of a country is equal to the gross virtual water export minus the gross virtual water import. Net virtual water import to a country has either a positive or a negative sign. The latter indicates that there is net virtual water export from the country. In this case, Egypt has net virtual water export $11.64 \mathrm{Tm}^{3} /$ year. The following figure (2) illustrates the economic water productivity for each year and the energetic water productivity for period (2008-2012).

It is quite clear that imported water economic productivity is lower than the exported water productivity. So Egypt has to stop exporting rice as it is not economic for Egypt. Where the one exported cubic meter is costing more than one imported cubic meter. For calculating the estimated planted area to cover the local consumption, the imported rice trade is about 0.35 Mton/year and the exported rice trade is nearly 2.43 Mton/year. But Egypt produces about 5.88 Mton/year. Therefore the estimated planted area is nearly $0.95 \mathrm{MFed} / \mathrm{year}$; the local consumption is approximately 3.8 Mton/year. 


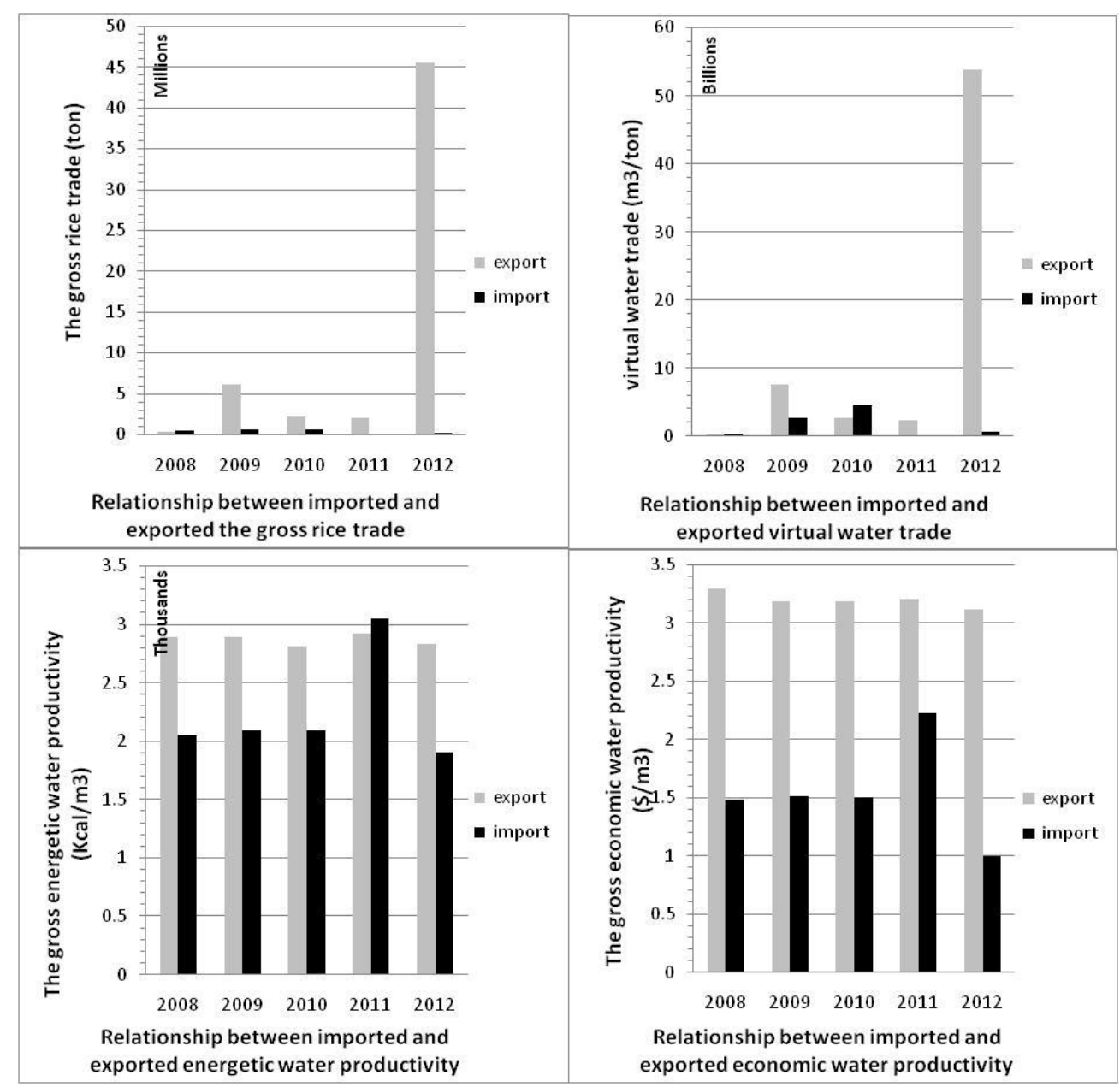

Fig. 2 The national virtual water trades balance of rice over the period 2008-2012.

\section{Wheat crop}

\section{1- Cropping area}

The total planted area of wheat in Egypt is about 3.4 MFed. As a whole is about $51.5 \%$ of the crop area is planted in Lower Egypt. Middle Egypt planted about $25.7 \%$ of total planted area. On the other side Upper Egypt planted about $15.8 \%$ of total area. There is about $7 \%$ of total planted area which planted in New Areas. The total planted area for wheat in (20082012) is shown in Table (4). 
Table 4: The total planted area of wheat (Feddan) over the period (2008-2012)

\begin{tabular}{c|llllll|}
\hline \multirow{2}{*}{$\begin{array}{c}\text { Egyptian } \\
\text { Region }\end{array}$} & \multicolumn{5}{|c|}{ Years } & \multirow{2}{*}{ Average } \\
\cline { 2 - 6 } & \multicolumn{1}{|c}{2008} & \multicolumn{1}{|c}{2009} & \multicolumn{1}{|c}{2010} & \multicolumn{1}{|c}{2011} & 2012 & \\
\hline Lower & 1620998 & 1822269 & 1694940 & 1737630 & 1799987 & 1735165 \\
Middle & 535598 & 566050 & 548730 & 2021863 & 650148 & 864478 \\
Upper & 507792 & 542049 & 522898 & 528623 & 564673 & 533207 \\
NewAreas & 255996 & 216660 & 225813 & 233485 & 235852 & 233561 \\
\hline Total area & 2920384 & 3147028 & 2992381 & 4521601 & 3250660 & 3366411 \\
\hline
\end{tabular}

\section{2- Total water footprint for wheat}

Figure 3 provides an overview of the water footprint of wheat $\left(\mathrm{m}^{3} / \mathrm{ton}\right)$ in the different regions of Egypt, over different years. As shown in this figure, it is noteworthy that, New Areas containing larger amounts of water footprint (about $3189 \mathrm{~m}^{3} /$ ton), Upper Egypt (about $2076 \mathrm{~m}^{3} /$ ton) and Middle Egypt (about $1708 \mathrm{~m}^{3} /$ ton), however, Lower Egypt containing smaller amounts of water footprint $\left(1511 \mathrm{~m}^{3} / \mathrm{ton}\right)$. This result may be explained by differences in yield, climate, and soil type for each region. The soil type in Lower Egypt is black and salty soil however Middle and Upper Egypt and New Areas are medium black and sandy soil. In Lower Egypt, the wheat yield is about 6.3 ton/ha however the yield in Upper Egypt and New Areas are 6.17 and 5.7 ton/ha respectively.

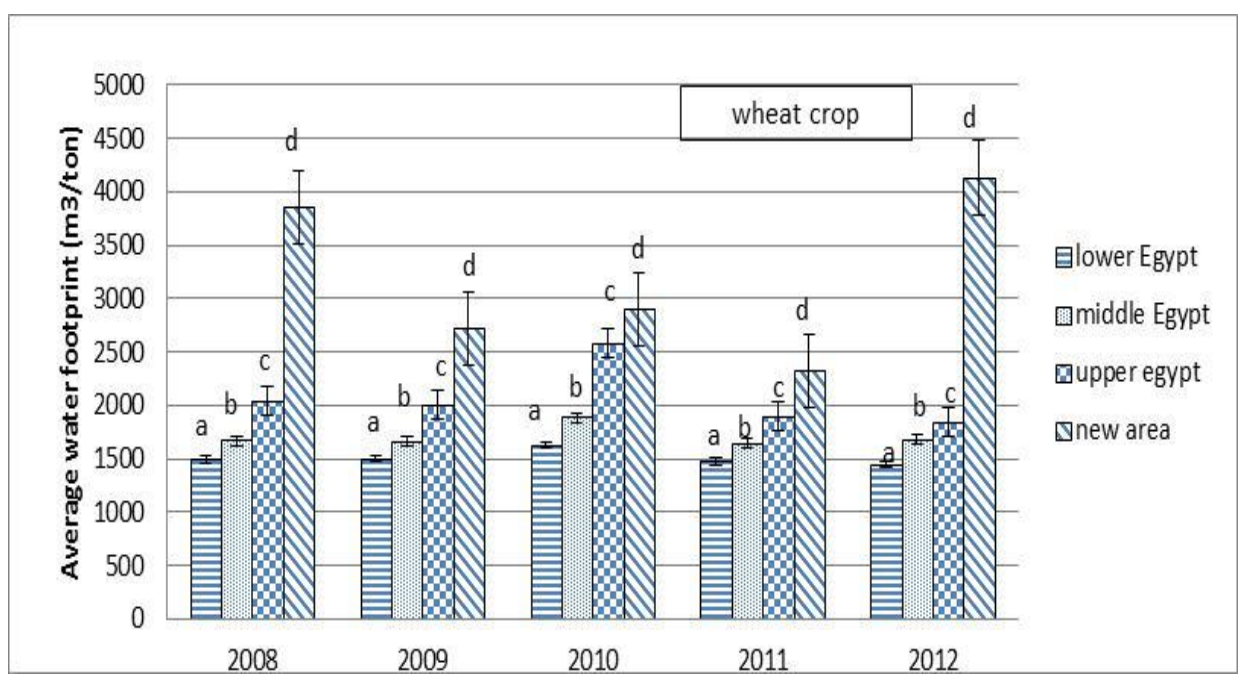

Fig. 3 Total water footprint of wheat over the period 2008-2012 
Table 5: Means, Standard Deviation and Duncan's Multiple Range Test for total water footprint of wheat in different regions over the period (2008-2012).

\begin{tabular}{c|cc|cc|cc|cc}
\multirow{2}{*}{ years } & \multicolumn{7}{|c}{ Egyptian regions } \\
\cline { 2 - 9 } & \multicolumn{2}{|c}{ Lower } & \multicolumn{2}{c}{ Middle } & \multicolumn{2}{c|}{ Upper } & \multicolumn{2}{c}{ New areas } \\
\cline { 2 - 9 } & Means & SD & Means & SD & Means & SD & Means & SD \\
\hline 2008 & $1496^{\mathrm{N}}$ & 152 & $1670^{\mathrm{N}}$ & 166 & $2042^{\mathrm{N}}$ & 347 & $3859^{*}$ & 2625 \\
2009 & $1503^{\mathrm{N}}$ & 150 & $1659^{\mathrm{N}}$ & 102 & $2004^{\mathrm{N}}$ & 409 & $2724^{*}$ & 1075 \\
2010 & $1628^{\mathrm{N}}$ & 167 & $1886^{\mathrm{N}}$ & 178 & $2587^{*}$ & 458 & $2904^{*}$ & 1004 \\
2011 & $1478^{\mathrm{N}}$ & 187 & $1642^{\mathrm{N}}$ & 114 & $1902^{\mathrm{N}^{*}}$ & 279 & $2328^{*}$ & 978 \\
2012 & $1448^{\mathrm{N}}$ & 221 & $1683^{\mathrm{N}}$ & 45 & $1848^{\mathrm{N}}$ & 363 & $4130^{*}$ & 4229 \\
\hline
\end{tabular}

$*$ and $\mathrm{N}$ having the same letter in each column are not significantly at $\mathrm{p}_{\mathrm{r}}<0.05$.

3- Energetic water productivity $\left(\mathrm{Kcal} / \mathrm{m}^{3}\right)$

The average water energetic productivity for Egypt is about 1797 $\mathrm{Kcal} / \mathrm{m}^{3}$.Concerning the energetic water productivity per region, Lower Egypt has the highest revenues per one cubic meter of water (about 2224 $\mathrm{Kcal} / \mathrm{m}^{3}$ ), followed by Middle and Upper Egypt (about 1954 and 1656 $\mathrm{Kcal} / \mathrm{m}^{3}$ ), New Areas have productivities of water less than 1355 $\mathrm{Kcal} / \mathrm{m}^{3}$ ). The highest water footprint is the lowest energetic water productivity as the energetic water productivity depends on water footprint.

\section{4- Economic water productivity $\left(\$ / \mathrm{m}^{3}\right)$}

The average water economic productivity for Egypt is about $1.5 \$ / \mathrm{m}^{3}$. As given from Table 6 Lower Egypt has the biggest economic water productivity so wheat should be planted in it to get high income. As well as, New Areas have the lowest economic water productivity so wheat should not be planted in New Areas. High economic productivity means that get high income from low water footprint so highest economic productivity region is preferred planting wheat with regard to Liqiang et.al. (2011).

5- Virtual water flows and the national virtual water trade balance

The net virtual water import of wheat is equal to the gross virtual water import minus the gross virtual water export. Net virtual water import has a positive sign. In this case, Egypt has net virtual water import 512.9 $\mathrm{Tm}^{3} /$ year. The following Figure (4) illustrates the economic water productivity for each year and the energetic water productivity for period (2008-2012). 
Table 6: Internal water footprint of produced wheat $\left(\mathrm{m}^{3} / \mathrm{ton}\right)$ for each region in Egypt over the period (2008-2012).

\begin{tabular}{|c|c|c|c|c|c|}
\hline \multirow{2}{*}{ Region } & \multicolumn{3}{|c|}{ Water footprint (m3/ton) } & \multirow{2}{*}{$\begin{array}{c}\text { Economic } \\
\text { water } \\
\text { productivity } \\
\left(\$ / \mathrm{m}^{3}\right)\end{array}$} & \multirow{2}{*}{$\begin{array}{c}\text { Energetic } \\
\text { water } \\
\text { productivity } \\
\left(\mathrm{Kcal} / \mathrm{m}^{3}\right)\end{array}$} \\
\hline & Green & Blue & Grey & & \\
\hline \multicolumn{6}{|c|}{2008} \\
\hline Lower Egypt & 14.5 & 987.4 & 494 & 2.34 & 2235.9 \\
\hline Middle Egypt & 6.4 & 1192.4 & 471 & 2.09 & 1999.4 \\
\hline Upper Egypt & 0 & 1531.6 & 510 & 1.74 & 1658.4 \\
\hline New areas & 143 & 2479.1 & 1237 & 1.25 & 1187.6 \\
\hline \multicolumn{6}{|c|}{2009} \\
\hline Lower Egypt & 10.8 & 990.9 & 502 & 2.33 & 2223.3 \\
\hline Middle Egypt & 0.8 & 1188.9 & 470 & 2.10 & 2003.6 \\
\hline Upper Egypt & 40.2 & 1449.8 & 514 & 1.79 & 1701.9 \\
\hline New areas & 94.9 & 1848.2 & 781 & 1.44 & 1375.3 \\
\hline \multicolumn{6}{|c|}{2010} \\
\hline Lower Egypt & 25.1 & 1065.2 & 538 & 2.32 & 2054.5 \\
\hline Middle Egypt & 58.2 & 1302.8 & 525 & 2.00 & 1770.1 \\
\hline Upper Egypt & 17.9 & 1903.9 & 665 & 1.48 & 1311.8 \\
\hline New areas & 148.3 & 1951.5 & 805 & 1.41 & 1244.9 \\
\hline \multicolumn{6}{|c|}{2011} \\
\hline Lower Egypt & 25.1 & 1065.2 & 538 & 2.32 & 2054.5 \\
\hline Middle Egypt & 58.2 & 1302.8 & 525 & 2.00 & 1770.1 \\
\hline Upper Egypt & 17.9 & 1903.9 & 665 & 1.48 & 1311.8 \\
\hline New areas & 148.3 & 1951.5 & 805 & 1.41 & 1244.9 \\
\hline \multicolumn{6}{|c|}{2012} \\
\hline Lower Egypt & 64.4 & 904.9 & 479 & 2.57 & 2334.4 \\
\hline Middle Egypt & 71.6 & 1149.2 & 462 & 2.17 & 1970.5 \\
\hline Upper Egypt & 96.6 & 1249.5 & 501.4 & 2.22 & 1838.9 \\
\hline New areas & 228 & 2515.3 & 1387.2 & 1.50 & 1375.4 \\
\hline
\end{tabular}

It is quite clear that, the exported water economic productivity is lower than imported water productivity so Egypt has to stop importing wheat because it is not economic. For calculating the estimated planted area to cover the local consumption, the imported wheat trade was about 420.6 Mton/year. But Egypt produced about 8.3 Mton/year. The local consumption was approximately $428.86 \mathrm{Mton} /$ year where the exported wheat trade was about $0.04 \mathrm{Mton} / \mathrm{year}$. The estimated planted area is nearly $135.2 \mathrm{MFed} / \mathrm{year}$ but it is a huge area to be planted wheat and it is not available to plant. So it is suggested to raise wheat yield and increase the planted area as possible. 


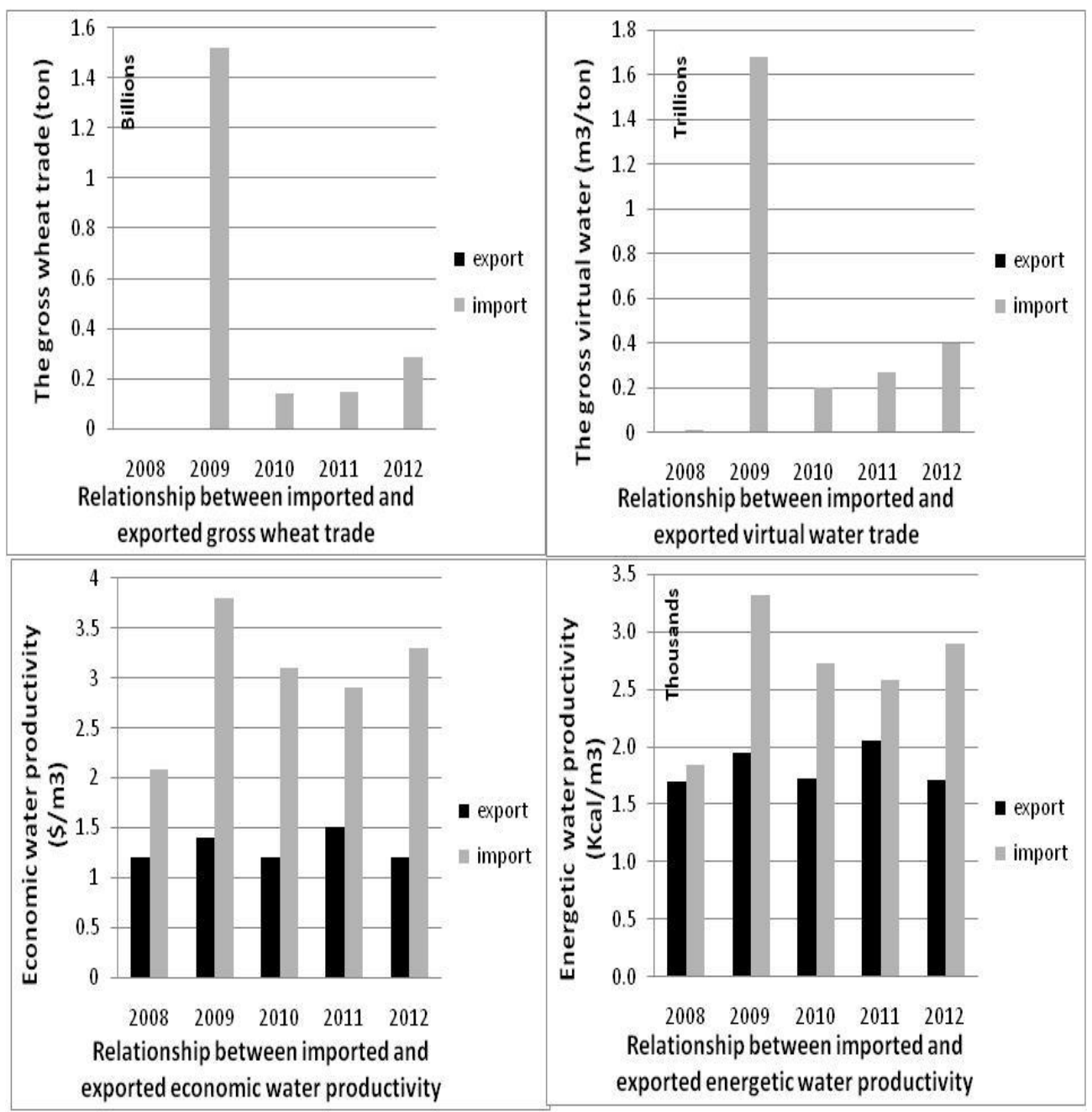

Fig. 4 The national virtual water trades balance of wheat over the period (2008-2012).

\section{Maize crop \\ 1- Cropping area}

The total planted area of maize in Egypt is about 1.95 MFed. As a whole $49 \%$ of the crop area is planted in Lower Egypt. Middle Egypt planted about $29 \%$ of total planted area. On the other side, Upper Egypt planted about $18 \%$ of total area. There is about $4 \%$ of total planted area which planted in New Areas. The total planted area for maize in (2008-2012) is shown in Table (7). 
Table 7: The total planted area of maize (Feddan) over the period (2008-2012).

\begin{tabular}{c|ccccc|c}
\hline Egyptian & \multicolumn{5}{|c|}{ Years } & \multirow{2}{*}{ Average } \\
\cline { 2 - 6 } Region & 2008 & 2009 & 2010 & 2011 & 2012 & \\
\hline Lower & 881926 & 931566 & 1056405 & 878027 & 1053619 & 960309 \\
Middle & 565582 & 619727 & 541503 & 496466 & 634209 & 571497 \\
Upper & 344516 & 347080 & 338343 & 314917 & 379866 & 344944 \\
New & 68339 & 79198 & 61997 & 69152 & 89382 & 73614 \\
\hline Total & 1860363 & 1977571 & 1998248 & 1758562 & 2157076 & 1950364 \\
\hline
\end{tabular}

\section{2- Total water footprint for maize}

Figure (5) provides an overview of the water footprint of maize $\left(\mathrm{m}^{3} / \mathrm{ton}\right)$ in the different regions of Egypt over different years. As shown in this figure, it is noteworthy that, New Areas containing larger amounts of water footprint (about $3464 \mathrm{~m}^{3} /$ ton), Upper Egypt (about $2486 \mathrm{~m}^{3} /$ ton) and Middle Egypt (about $1822 \mathrm{~m}^{3} /$ ton), however, Lower Egypt containing smaller amounts of water footprint (about $1601.6 \mathrm{~m}^{3} /$ ton). This result may be explained by differences in yield, climate, and soil type for each region. In Lower Egypt, maize yield is about 8.2 ton/ha however yield in Upper Egypt and New Areas are about 6.1 and 5.7 ton/ha. As clear from results that, Lower Egypt quite has the lowest water footprint so it preferred planting maize.

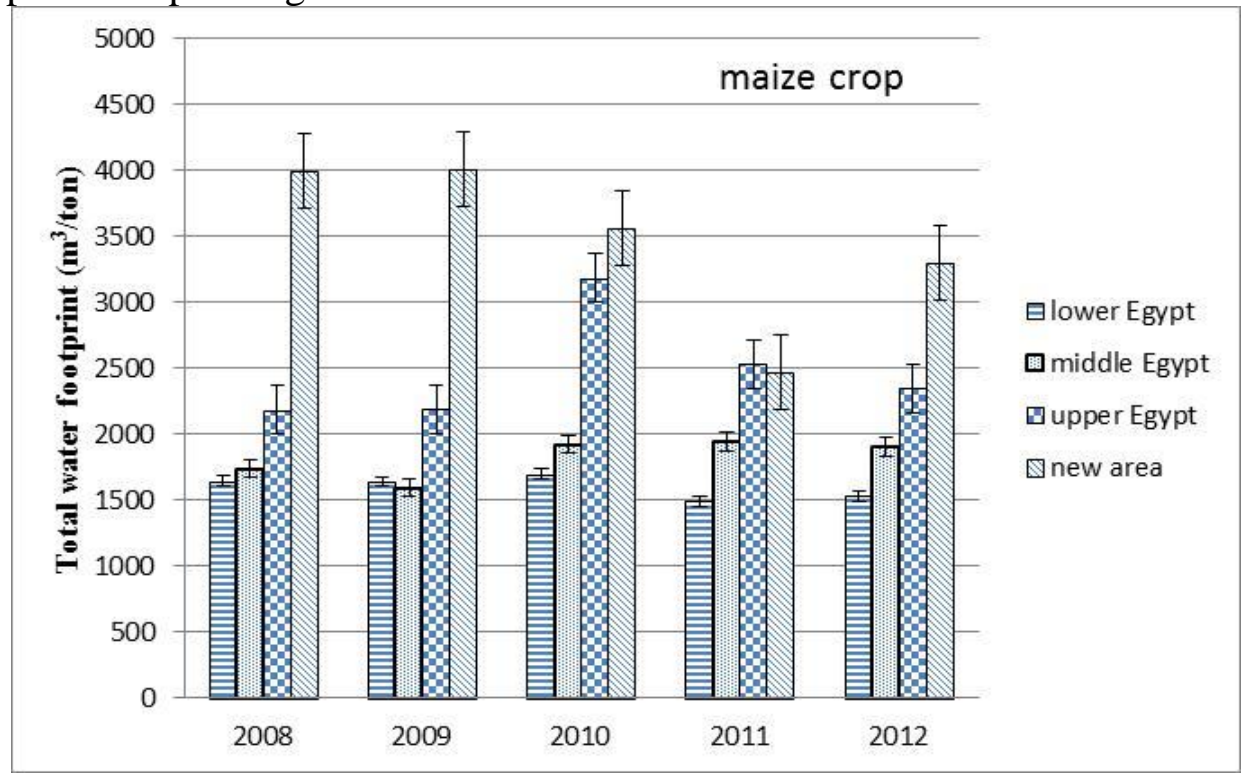

Fig.5 Total water footprint of Maize over the period 2008-2012 


\section{3- Energetic water productivity $\left(\mathrm{Kcal} / \mathrm{m}^{3}\right)$}

The average water energetic productivity for Egypt is about 2263 $\mathrm{Kcal} / \mathrm{m}^{3}$. Concerning the energetic water productivity per region, Lower Egypt has the highest revenues per one cubic meter of water (2956 $\mathrm{Kcal} / \mathrm{m}^{3}$ ), followed by Middle and Upper Egypt (about 2435 and 1825 $\mathrm{Kcal} / \mathrm{m}^{3}$ ), New Areas have productivities of water less than 1833 $\mathrm{Kcal} / \mathrm{m}^{3}$ ). The highest water footprint is the lowest energetic water productivity as the energetic water productivity depends on water footprint.

Table 8: Means, Standard Deviation and Duncan's Multiple Range Test for total water footprint of maize in different regions over the period (2008-2012)

\begin{tabular}{c|cc|cc|cc|cc}
\hline \multirow{2}{*}{ years } & \multicolumn{8}{|c}{ Egyptian regions } \\
\cline { 2 - 9 } & \multicolumn{2}{|c}{ Lower } & \multicolumn{2}{c|}{ Middle } & \multicolumn{2}{c|}{ Upper } & \multicolumn{2}{c}{ New areas } \\
\cline { 2 - 9 } & Means & SD & Means & SD & Means & SD & Means & SD \\
\hline 2008 & $1643^{\mathrm{N}}$ & 332 & $1736^{\mathrm{N}}$ & 295 & $2182^{\mathrm{N}}$ & 536 & $3997^{*}$ & 2738 \\
2009 & $1640^{\mathrm{N}}$ & 398 & $1599^{\mathrm{N}}$ & 278 & $2189^{\mathrm{N}}$ & 581 & $4006^{*}$ & 3167 \\
2010 & $1700^{\mathrm{N}}$ & 507 & $1929^{\mathrm{N}}$ & 480 & $3181^{\mathrm{N}^{*}}$ & 646 & $2559^{*}$ & 3101 \\
2011 & $1492^{\mathrm{N}}$ & 226 & $1943^{\mathrm{N}}$ & 300 & $2531^{*}$ & 672 & $2469^{*}$ & 978 \\
2012 & $1533^{\mathrm{N}}$ & 281 & $1905^{\mathrm{N}}$ & 252 & $2532^{\mathrm{N}^{*}}$ & 530 & $3293^{*}$ & 2590 \\
\hline
\end{tabular}

$*$ and $\mathrm{N}$ having the same letter in each column are not significantly at $\mathrm{p}_{\mathrm{r}}<0.05$.

\section{4- Economic water productivity $\left(\$ / \mathrm{m}^{3}\right)$}

The average water economic productivity for Egypt is about $2 \$ / \mathrm{m}^{3}$. High economic productivity means that get high income from low water footprint. As given from Table 9 the Lower Egypt has the highest economic water productivity so maize should be planted in it to get high income. As well as, New Areas have the lowest economic water productivity so maize has not to be planted in New Areas.

\section{5- Virtual water flows and the national virtual water trade balance}

The net virtual water import of maize is equal to the gross virtual water import minus the gross virtual water export. Net virtual water import has a positive sign. In this case, Egypt has net virtual water import 106.8 $\mathrm{Tm}^{3} /$ year. The following Figure (6) illustrates the economic water productivity for each year and the energetic water productivity for period (2008-2012). 
Table 9: Internal water footprint of maize produced $\left(\mathrm{m}^{3} / \mathrm{ton}\right)$ for each region in Egypt over the period (2008-2012)

\begin{tabular}{|c|c|c|c|c|c|c|}
\hline \multirow{2}{*}{ Region } & \multicolumn{4}{|c|}{$\begin{array}{l}\text { Water footprint } \\
\left(\mathrm{m}^{3} / \text { ton }\right)\end{array}$} & \multirow{2}{*}{$\begin{array}{c}\text { Economic } \\
\text { water } \\
\text { productivit } \\
\mathrm{y}\left(\$ / \mathrm{m}^{3}\right)\end{array}$} & \multirow{2}{*}{$\begin{array}{c}\text { Energetic } \\
\text { water } \\
\text { productivity } \\
\left(\mathrm{Kcal} / \mathrm{m}^{3}\right)\end{array}$} \\
\hline & Green & Blue & Grey & Total & & \\
\hline \multicolumn{7}{|c|}{2008} \\
\hline lower Egypt & 24.3 & 933.4 & 685.5 & 1643.2 & 2.3 & 2794.9 \\
\hline middleEgypt & 22.5 & 1073.0 & 640.0 & 1735.6 & 2.2 & 2541.9 \\
\hline Upper Egypt & 30.6 & 1411.6 & 739.6 & 2181.8 & 1.8 & 2025.9 \\
\hline New areas & 40.8 & 2306.6 & 1650.0 & 3997.5 & 1.3 & 1586.7 \\
\hline \multicolumn{7}{|c|}{2009} \\
\hline lower Egypt & 16.3 & 937.6 & 686.9 & 1640.8 & 2.44 & 2817.7 \\
\hline middleEgypt & 6.2 & 988.3 & 604.7 & 1599.2 & 2.5 & 2777.6 \\
\hline Upper Egypt & 17.0 & 1423.6 & 748.1 & 2188.8 & 1.9 & 2038.9 \\
\hline New areas & 11.8 & 2363.7 & 1630.8 & 4006.3 & 1.5 & 1711.6 \\
\hline \multicolumn{7}{|c|}{2010} \\
\hline lower Egypt & 45.4 & 955.2 & 699.0 & 1699.6 & 2.47 & 2765.2 \\
\hline middleEgypt & 54.8 & 1197.9 & 676.4 & 1929.1 & 2.24 & 2330.5 \\
\hline Upper Egypt & 17.4 & 2135.7 & 1027.8 & 3181.0 & 1.4 & 1359.5 \\
\hline New areas & 7.9 & 2043.4 & 1507.2 & 3558.5 & 1.7 & 1880.7 \\
\hline \multicolumn{7}{|c|}{2011} \\
\hline lower Egypt & 7.2 & 856.9 & 627.8 & 1491.9 & 2.6 & 3171.6 \\
\hline middleEgypt & 13.4 & 1234.3 & 696.2 & 1943.9 & 2.02 & 2245.6 \\
\hline Upper Egypt & 11.0 & 1659.8 & 860.8 & 2531.6 & 1.6 & 1746.4 \\
\hline New areas & 24.7 & 1458.6 & 985.9 & 2469.2 & 1.8 & 2053.0 \\
\hline \multicolumn{7}{|c|}{2012} \\
\hline lower Egypt & 35.6 & 863.6 & 633.7 & 1532.9 & 2.58 & 3231.5 \\
\hline middleEgypt & 44.5 & 1167.9 & 692.4 & 1904.9 & 2.05 & 2279.1 \\
\hline Upper Egypt & 16.1 & 1503.7 & 827.1 & 2346.9 & 1.71 & 1956.7 \\
\hline New areas & 10.9 & 1894.6 & 1387.2 & 3292.6 & 1.69 & 1936.9 \\
\hline
\end{tabular}

It is quite clear that the exported water economic productivity is lower than imported water productivity. So Egypt has to stop importing maize because it is not economic. For calculating the estimated planted area to cover the local consumption, the imported maize trade is about 114.9 Mton/year. But Egypt produces about 6.5 Mton/year. The local consumption is approximately $121.16 \mathrm{Mton} / \mathrm{year}$ where exported maize trade is about $0.015 \mathrm{Mton} / \mathrm{year}$. The estimated planted area is nearly 36.7 MFed/year but it is a huge area to be planted maize and it is not available to plant. So it is suggested to raise maize yield and increase the planted area as possible. 


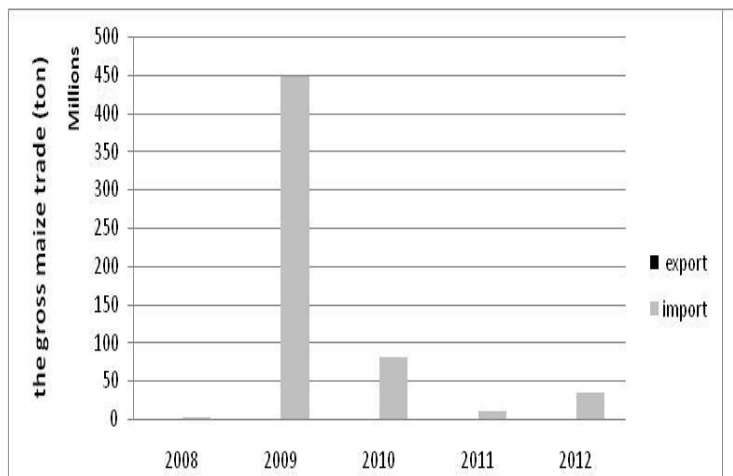

Relationship between import and export Maize trade

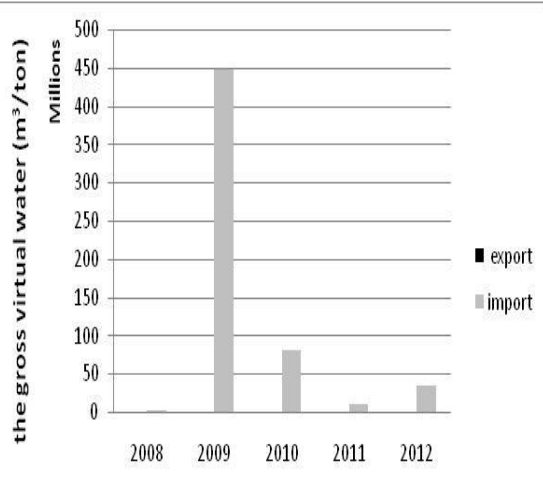

Relationship between import and export virtual water
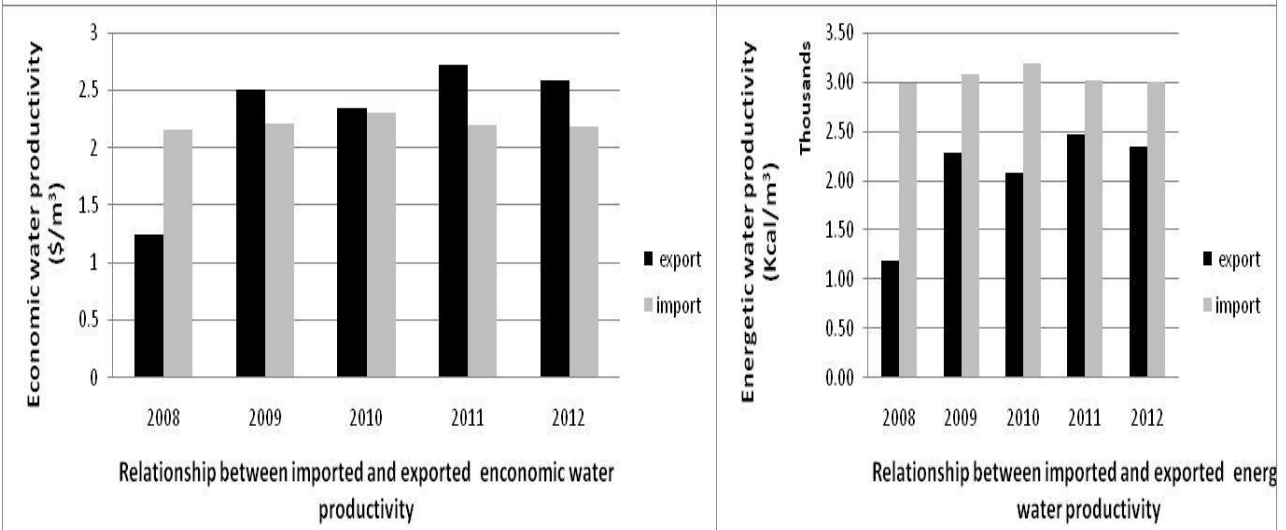

Fig. 6 The national virtual water trades balance of maize over the period (2008-2012).

\section{Sugarcane crop}

\section{1- Cropping area}

The total planted area of sugarcane in Egypt is about 322879 Fed. As a whole $1.13 \%$ of the crop area is planted in Lower Egypt. Middle Egypt planted about $13 \%$ of total planted area. On the other side Upper Egypt planted about $85.8 \%$ of total area. There is about $0.096 \%$ of total planted area which planted in new areas. The total planted area for sugarcane in (2008-2012) is shown in Table (10).

\section{2- Total water footprint for sugarcane}

Figure (7) provides an overview of the water footprint of sugarcane $\left(\mathrm{m}^{3} /\right.$ ton $)$ for the different regions in Egypt over different years. As shown in this figure, it is noteworthy that, New Areas containing larger amounts of water footprint (about $1101.52 \mathrm{~m}^{3} /$ ton), Middle Egypt (about 368 
$\mathrm{m}^{3} /$ ton) and, Lower Egypt (about $300 \mathrm{~m}^{3} /$ ton) however, Upper Egypt containing smaller amounts of water footprint (about $288 \mathrm{~m}^{3} /$ ton). This result may be explained by the differences in yield, climate, and soil type for each region, there are different in water footprint. In Upper Egypt, sugarcane yield is about 106.5 ton/ha however yield in Middle Egypt and New Areas are 82 and 23.5 ton/ha. As clear from results that, Upper Egypt has the lowest water footprint so sugarcane is preferred to planted in Upper Egypt.

Table 10: The total planted area of Sugarcane (Fadden) over the period (2008-2012)

\begin{tabular}{c|ccccc|c}
\hline Egyptian & \multicolumn{5}{|c|}{ Years } & \multirow{2}{*}{ Average } \\
\cline { 2 - 6 } Region & 2008 & 2009 & 2010 & 2011 & 2012 & \\
\hline Lower & 2521 & 3087 & 3264 & 3515 & 5853 & 3648 \\
Middle & 41467 & 40906 & 42245 & 42487 & 42155 & 41852 \\
Upper & 279246 & 272560 & 274485 & 279068 & 279984 & 277069 \\
New Areas & 356 & 159 & 159 & 428 & 450 & 310 \\
\hline Total area & 323590 & 316712 & 320153 & 325498 & 328442 & 322879 \\
\hline
\end{tabular}

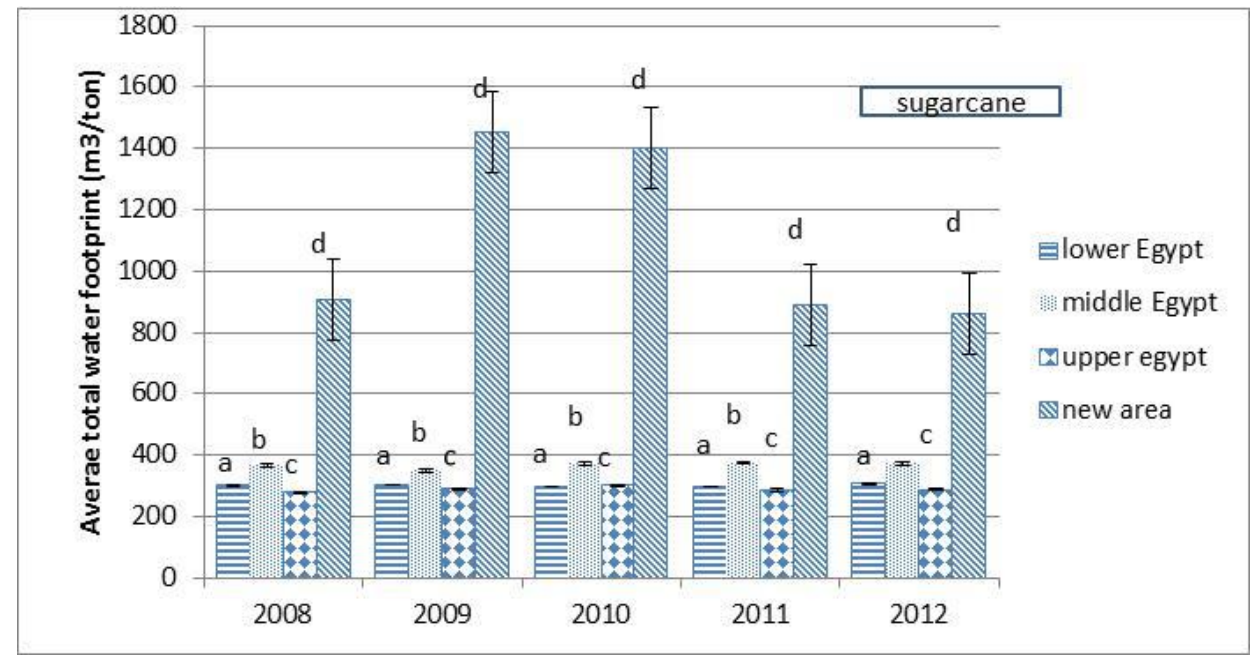

Fig. 7 Total water footprint of Sugarcane over the period 2008-2012

\section{3- Energetic water productivity $\left(\mathrm{Kcal} / \mathrm{m}^{3}\right)$}

The average water energetic productivity for Egypt is about 1031.4 $\mathrm{Kcal} / \mathrm{m}^{3}$. Concerning the energetic water productivity per region, Upper Egypt has the highest revenues per one cubic meter of water (1367 
$\mathrm{Kcal} / \mathrm{m}^{3}$ ), followed by Lower and Middle Egypt (about 1312 and $1082 \mathrm{Kcal} / \mathrm{m}^{3}$ ), New Areas have productivities of water less than 364 $\mathrm{Kcal} / \mathrm{m}^{3}$ ). The highest water footprint is the lowest energetic water productivity because of the energetic water productivity depends on water footprint.

Table 11: Means, Standard Deviation and Duncan's Multiple Range Test for total water footprint of sugarcane in different regions over the period (2008-2012).

\begin{tabular}{c|cc|cc|cc|cc}
\hline \multirow{2}{*}{ Years } & \multicolumn{7}{c}{ Egyptian regions } \\
\cline { 2 - 9 } & \multicolumn{2}{|c|}{ Lower } & \multicolumn{2}{c|}{ Middle } & \multicolumn{2}{c}{ Upper } & \multicolumn{2}{c}{ New areas } \\
\cline { 2 - 9 } & Means & SD & Means & SD & Means & SD & Means & SD \\
\hline 2008 & $300^{\mathrm{N}}$ & 55 & $366^{\mathrm{N}}$ & 80 & $277^{\mathrm{N}}$ & 51 & $906^{*}$ & - \\
2009 & $310^{\mathrm{N}}$ & 52 & $346^{\mathrm{N}}$ & 78 & $289^{\mathrm{N}}$ & 59 & $1451^{*}$ & - \\
2010 & $305^{\mathrm{N}}$ & 61 & $371^{\mathrm{N}}$ & 100 & $302^{\mathrm{N}}$ & 63 & $1399^{*}$ & - \\
2011 & $297^{\mathrm{N}}$ & 62 & $375^{\mathrm{N}}$ & 102 & $286^{\mathrm{N}}$ & 59 & $890^{*}$ & - \\
2012 & $306^{\mathrm{N}}$ & 71 & $373^{\mathrm{N}}$ & 111 & $288^{\mathrm{N}}$ & 75 & $862^{*}$ & - \\
\hline
\end{tabular}

$*$ and $\mathrm{N}$ having the same letter in each column are not significantly at $\mathrm{p}_{\mathrm{r}}<0.05$.

\section{4- Economic water productivity $\left(\$ / \mathrm{m}^{3}\right)$}

The average water economic productivity for Egypt is about $1.36 \$ / \mathrm{m}^{3}$. High economic productivity means that get high income from low water footprint. As given from Table (12) the Upper Egypt has the highest economic water productivity so sugarcane should be planted in it to get high income. As well as, New Areas have the lowest economic water productivity so sugarcane has not to be planted in New Areas.

\section{5- Virtual water flows and the national virtual water trade balance}

The net virtual water import of sugar is equal to the gross virtual water import minus the gross virtual water export. Net virtual water import has a positive sign. In this case, Egypt has net virtual water import 132.9 $\mathrm{Mm}^{3} /$ year. The following Figure (8) illustrates the economic water productivity for each year and the energetic water productivity for period (2008-2012). 
Table 12: Internal water footprint of sugar cane produced $\left(\mathrm{m}^{3} /\right.$ ton) for each region in Egypt over the period (2008-2012)

\begin{tabular}{|c|c|c|c|c|c|c|}
\hline \multirow{2}{*}{ Region } & \multicolumn{4}{|c|}{$\begin{array}{l}\text { Water footprint } \\
\left(\mathrm{m}^{3} / \text { ton }\right)\end{array}$} & \multirow{2}{*}{$\begin{array}{c}\text { Economic } \\
\text { water } \\
\text { productivit } \\
\mathrm{y}\left(\$ / \mathrm{m}^{3}\right)\end{array}$} & \multirow{2}{*}{$\begin{array}{c}\text { Energetic } \\
\text { water } \\
\text { productivity } \\
\left(\mathrm{Kcal} / \mathrm{m}^{3}\right)\end{array}$} \\
\hline & Green & Blue & Grey & Total & & \\
\hline \multicolumn{7}{|c|}{2008} \\
\hline lower Egypt & 2.4 & 266.6 & 30.7 & 299.7 & 1.40 & 1309.4 \\
\hline middleEgypt & 2.7 & 332.1 & 31.4 & 366.2 & 1.12 & 1080.1 \\
\hline Upper Egypt & 0.3 & 256.4 & 20.8 & 277.4 & 1.50 & 1406.1 \\
\hline New areas & 0 & 807.4 & 99.0 & 906.4 & 0.44 & 418.9 \\
\hline \multicolumn{7}{|c|}{2009} \\
\hline lower Egypt & 4.3 & 268.4 & 30.8 & 303.5 & 1.41 & 1285.1 \\
\hline middleEgypt & -3.7 & 323.8 & 30.3 & 350.4 & 1.23 & 1120.4 \\
\hline Upper Egypt & 17.7 & 249.3 & 21.8 & 288.8 & 1.50 & 1359.1 \\
\hline New areas & 0 & 1294.5 & 156.0 & 1450.5 & 0.29 & 261.8 \\
\hline \multicolumn{7}{|c|}{2010} \\
\hline lower Egypt & 2.4 & 265.1 & 30.0 & 297.5 & 1.49 & 1321.7 \\
\hline middleEgypt & 5.2 & 337.6 & 30.2 & 372.9 & 1.20 & 1064.7 \\
\hline Upper Egypt & 1.6 & 278.6 & 21.6 & 301.8 & 1.47 & 1303.8 \\
\hline New areas & 0 & 1243.3 & 156.0 & 1399.3 & 0.31 & 271.4 \\
\hline \multicolumn{7}{|c|}{2011} \\
\hline lower Egypt & 7.5 & 258.7 & 30.8 & 296.9 & 1.51 & 1335.1 \\
\hline middleEgypt & 3.5 & 341.2 & 30.8 & 375.4 & 1.16 & 1070.6 \\
\hline Upper Egypt & 0.4 & 264.0 & 21.8 & 286.2 & 1.51 & 1376.9 \\
\hline New areas & 0 & 785.7 & 103.9 & 889.6 & 0.47 & 426.9 \\
\hline \multicolumn{7}{|c|}{2012} \\
\hline lower Egypt & 6.3 & 269.1 & 30.9 & 306.3 & 1.48 & 1307.3 \\
\hline middleEgypt & 3.7 & 338.9 & 30.8 & 373.4 & 1.15 & 1075.9 \\
\hline Upper Egypt & 0.4 & 264.2 & 23.0 & 287.6 & 1.53 & 1391.3 \\
\hline New areas & 27.6 & 732.9 & 101.3 & 861.7 & 0.48 & 440.7 \\
\hline
\end{tabular}

It is quite clear that the exported water economic productivity is lower than imported water productivity. So Egypt has to stop exporting sugarcane because it is not economic. For calculating the estimated planted area to cover the local consumption, the imported and exported sugarcane trades are about 2.4 and 0.19 Mton/year. But Egypt produces about 15 Mton/year. Therefore the estimated planted area is nearly $369484.92 \mathrm{Fed} / \mathrm{year}$; the local consumption was approximately 17.14 Mton/year. 


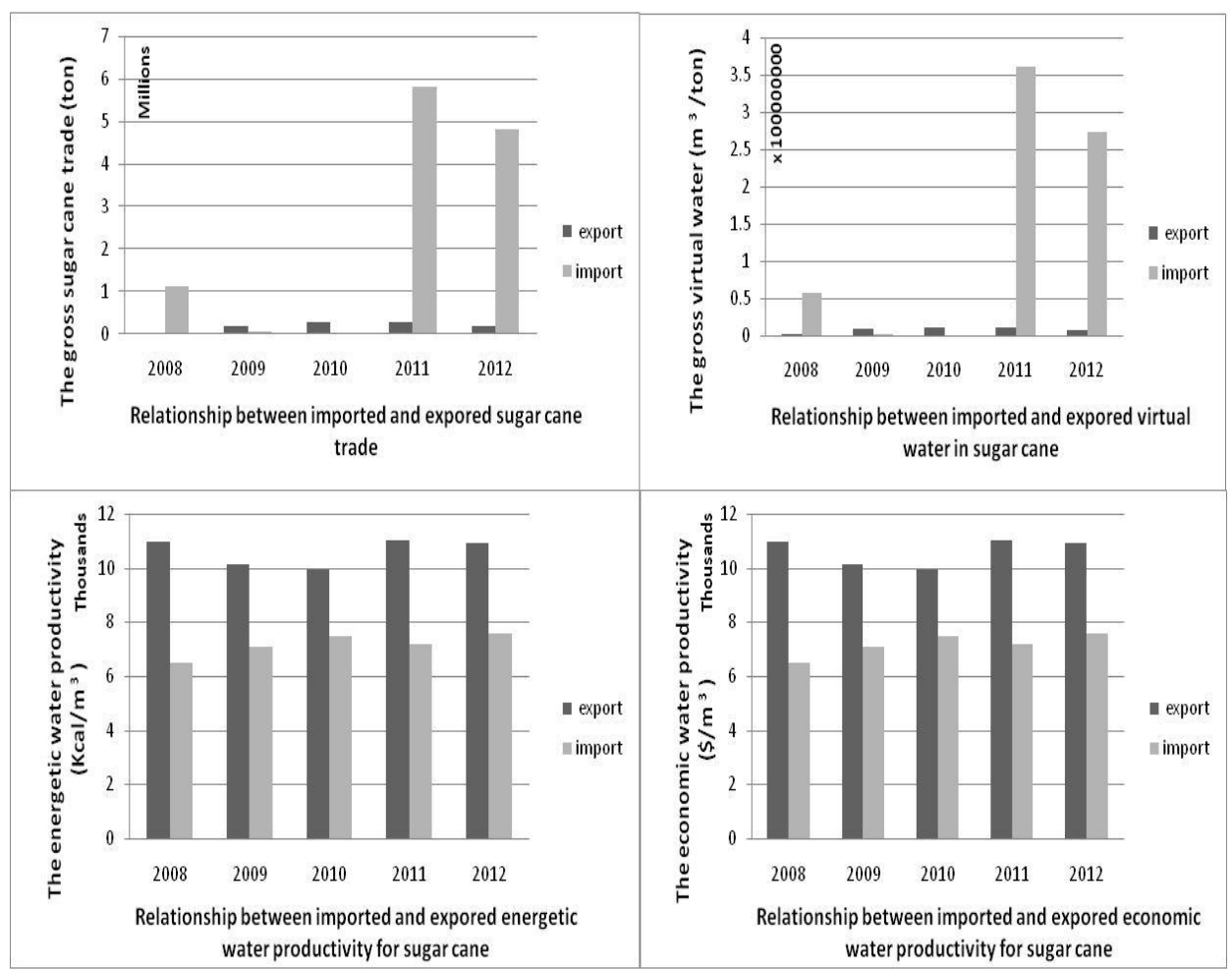

Fig. 8 The national virtual water trades balance of sugarcane over the period (2008-2012).

\section{CONCLUSIONS}

The analyses of water footprint and virtual water trade provide very interesting results as follows:

a) Rice crop

As seen from results that Lower Egypt has the lowest water footprint $\left(1435.9 \mathrm{~m}^{3} /\right.$ ton $)$ and highest economic productivity $\left(3 \$ / \mathrm{m}^{3}\right)$. So it is recommened to cultivate rice in Lower Egypt. There are two words should be stated in the section related to the virtual water flow balances for rice, stop exporting rice. The one cubic meter of water used in rice production in Egypt costs $3 \$$, but the imported one cubic water in rice costs about $1.5 \$$. So it is suggested to cultivate about 937016 Fed rice in Lower Egypt to cover the national consumption.

b) Wheat crop

It is quite clear that Lower Egypt has the lowest water footprint (1511 $\mathrm{m}^{3} /$ ton) and highest economic productivity $\left(1.95 \$ / \mathrm{m}^{3}\right)$. So Lower Egypt 
is the place where Egypt has to plant wheat. In the section related to the virtual water flow balances for rice, The one cubic meter of water used in wheat production costs $1.8 \$$, but the imported one cubic water of rice getting income about $3 \$$. In Egypt, there are a huge deficit between the production and national consumption. To cover this deficit, Egypt has to plant about 135.2 MFed of wheat per year. But it is a huge area and this area not available. So it is important to raise wheat yield and increase planted area as possible.

c) Maize crop

Lower Egypt has the lowest water footprint $\left(1602 \mathrm{~m}^{3} / \mathrm{ton}\right)$ and highest economic productivity $\left(2.5 \$ / \mathrm{m}^{3}\right)$. So Lower Egypt is the place where Egypt has to plant maize. It is quite clear that annual Egypt maize consumption is about 121.2 Mton/year. The one cubic meter of water used in maize production in Egypt costs $2 \$$, but the imported one cubic water of maize costs about $3 \$$. Egypt has to stop importing maize. So Egypt has to plant about $36.7 \mathrm{MFed} /$ year to cover nation consumption but it is a huge area and this area not available. So it is important to raise maize yield and increase planted area as possible.

d) Sugarcane crop

As seen from results that Upper Egypt has the lowest water footprint (288 $\mathrm{m}^{3} /$ ton) and highest economic productivity $\left(1.44 \$ / \mathrm{m}^{3}\right)$. So it is important to cultivate sugarcane in Upper Egypt. There are two words should be stated in the section related to the virtual water flow balances for sugarcane, stop exporting sugar. The one cubic meter of water using in sugarcane production in Egypt costs $10 \$$, but the imported one cubic water in rice costs about $7 \$$. So it is suggested to cultivate about 3694984.9 Fed sugarcane to cover national consumption.

\section{REFERENCES}

Aldaya. M.M and M.R. Llamas, (2008). Water footprint analysis for the Guadiana river basin. Available at: http://www. waterfootprint.org/ Reports/Report35.pdf. Accessed on 10 Feb 2013. Value of water research report series No (35), pp 1-86. 
Aldaya.M.M, M.R. Llamas and Pedro Martínez-Santos (2009). Incorporating the Water Footprint and Virtual Water into Policy: Reflections from the Mancha Occidental Region, Spain. Available at: http://www.rac.es/ficheros/doc/00745.pdf Accessed on 24 Sep 2013. Water Resource Manage (2010) 24, pp 941-958.

Bulsink, F., A. Hoekstra, M.J. Booij, (2010). The water footprint of Indonesian provinces related to the consumption of crop products. Hydrol. Earth Syst. Sci. (14), PP 119-128.

Chapagain, A.K. and A.Y. Hoekstra. (2003). Virtual water trade: A quantification of virtual water flows between nations in relation to international trade of livestock and livestock products. In: Hoekstra (ED) .Virtual water trade: Proceedings of the International Expert Meeting on Virtual Water Trade. Value of Water Research Report Series No. (12), pages 248, UNESCO-IHE Institute for Water Education, Delft, the Netherlands.

Chapagain, A. K. and A. Y. Hoekstra. (2004). Water footprints of nations. Available at: www. waterfootprint.org/Reports/ Report 16 Vol1.pdf. Accessed on 30 Feb 2013, Value of Water Research Report Series No (16), Pages 80, UNESCO-IHE, and Delft, Netherlands.

Chapagain, A. K. and A. Y. Hoekstra. (2010). The green, blue and grey water footprint of rice from both a production and consumption perspective. Available at: http://doc.utwente.nl /77194/1/Report40WaterFootprintRice.pdf. Accessed on 19 Sep 2013, Value of Water Research Report Series No (40), Pages 62, UNESCO-IHE, and Delft, Netherlands.

Cong, L. and U. N. Stephen (2009). Investigating the water footprint of Tetra Pak Carton Economy's beverage portfolio, Available at: http://lup.lub.lu.se/luur/download? func=downloadFile\&recordOI $\underline{\mathrm{d}=1543438 \& \text { fileOId}=1543442}$ accessed on: 19 Sep 2013. Page:167.

FAO (2003). Technical Conversion Factors for Agricultural Commodities. Available at: http://www.fao.org/fileadmin 
/templates/ess/documents/methodology/tcf.pdf. Accessed on: 30 Sep 2014.page 1:728.

FAO (2010b). CROPWAT 8.0 model. Available at: www.fao.org/nr /water/infores_databases_cropwat.html. Accessed on: 20 Apr 2015. FAO, Rome,PP 1-75.

Hoekstra, A.Y. and P.Q. Hung. (2002). A quantification of virtual water flows between nations in relation to international crop trade. Value of Water Research Report Series No (11), PP 1-120, UNESCO-IHE Institute for Water Education, Delft, the Netherlands.

Hoekstra, A. Y. and P. Q. Hung. (2005). Globalisation of water resources: international virtual water flows in relation to crop trade, Global Environmental Change 15(1), PP 45-56.

Hoekstra, A. Y. and A. K. Chapagain, (2008). Globalization of Water: Sharing the Planet's Freshwater Resources, Blackwell Publishing, Oxford. Published Online: 7 APR 2008 DOI: 10.1002 / 9780470696224.

Hoekstra, A.Y., A.K. Chapagain, M.M. Aldaya, and M.M. Mekonnen. (2011). The water footprint assessment manual. Available at:http://www.waterfootprint.org/downloads/ Accessed on 25 Jan.2013. Water Footprint Network 2011.Pages 228.

Liu, J. and H.H.G. Savenije, (2008). Food consumption patterns and their effect on water requirement in China. Hydrol. Earth Syst. Sci. (12), PP 887-898.

Liqiang, G., X. Gaodi, Z. Caixia, L. Shimei, Q. Yue, C. Shuyan, and H. Tingting, (2011). An evaluation of Chain's water footprint. Available at: http://www.sze.hu/fk/kornyezet/Cikkek9/ AnEvaluation-of-China-s-Water-Footprint_2011_Water-ResourcesManagement.pdf. Accessed on 3 Feb 2013. Water Resource Manage (2011) 25. PP 2633-2647.

Van Oel, P., M. Mekonnen, and A. Hoekstra, (2009). The external water footprint of the Netherlands: geographically-explicit quantification and impact assessment. Ecol. Econ. (69), PP 82-92. 
Verma, S., D.A. Kampman, P. van der Zaag, A.Y. Hoekstra, (2009). Going against the flow: a critical analysis of inter-state virtual water trade in the context of India's National River Linking Program. Physical Chemical Earth 34, PP 261-269.

World Bank. GDP per unit of energy use (\$ per kg of oil equivalent).

Available at: www.worldbank.org. Accessed on: 17Apr 2015. Sheet 1.

\section{الملخص العربى}

دراسة عن المياه العابرة للحدود والبصمة المائية لبعض المحاصيل فى مصر المريع

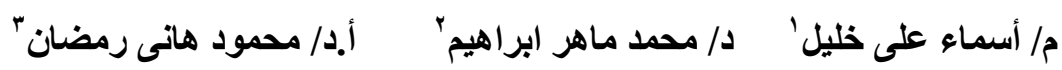
عن طريق الربط بين مجموعة من المؤشرات و القضايا وجد أن تحليل البصمة المائية و المياه

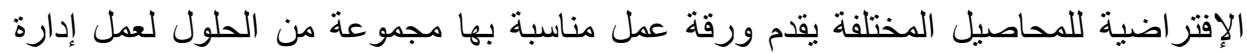

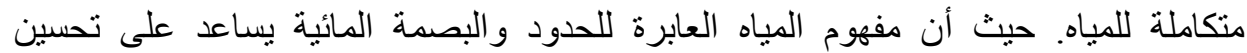

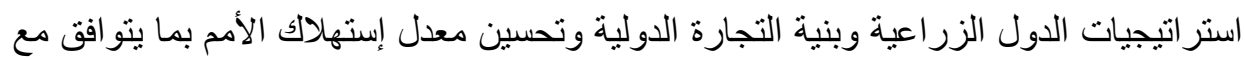

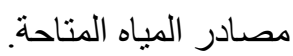

ولهذا تم إجر اء تحليل للبصمة المائية و المياه الإفتراضية لمجمو عه من المحاصيل وهى الأرز

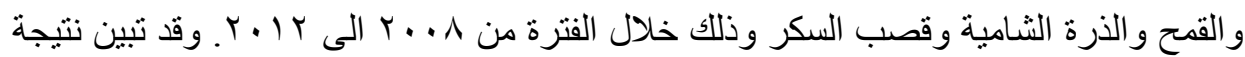

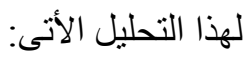

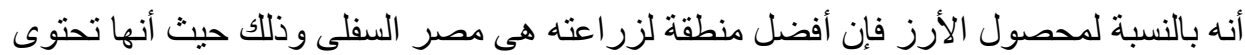

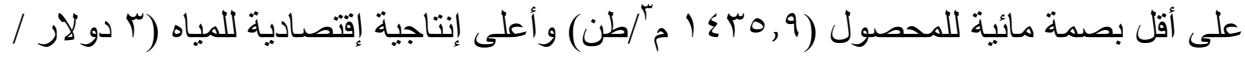

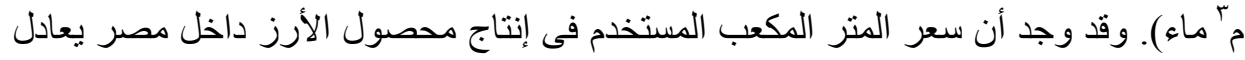

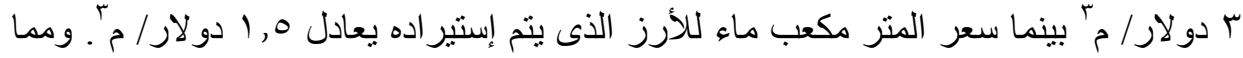

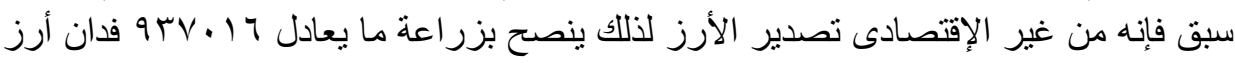

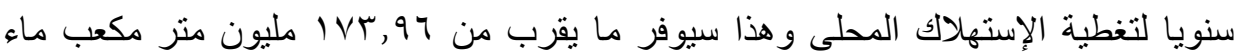

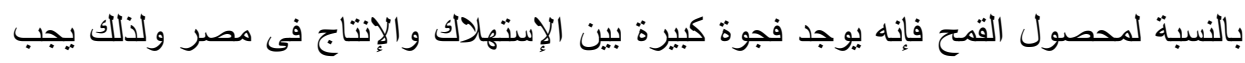

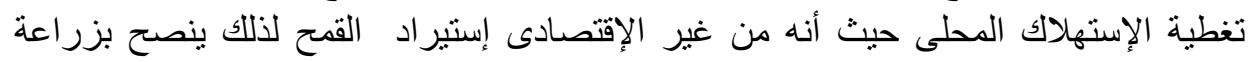

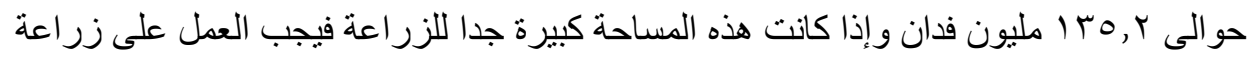

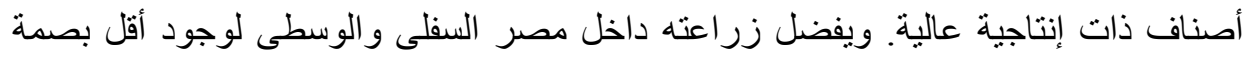
مائية له و أعلى إنتاجية إقتصادية للمياه.

' 'أخصائى زراعى- بمعهل بحوث الهندسة الزراعيةـ بالاقيى- القاهرة

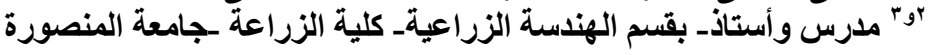


بينما نتائج محصول الذرة الثامبة فقد أتضح أن أفضل منطقة لزر اعته هى مصر السفلى وذلك

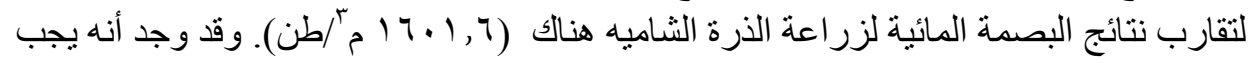
إيقاف إستير اد الذرة وتغطية الإستهلاك المحلى فقط حيث أن سعر المثر المكعب المستخدم فى المى

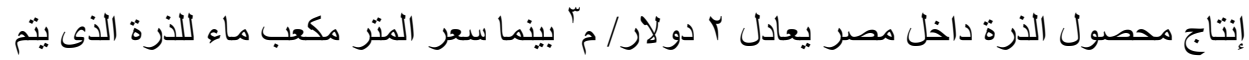

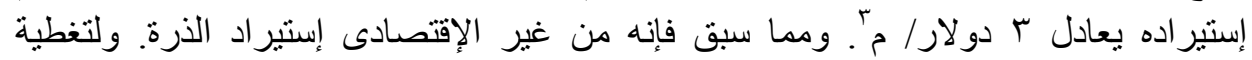

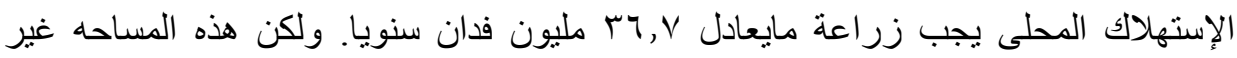

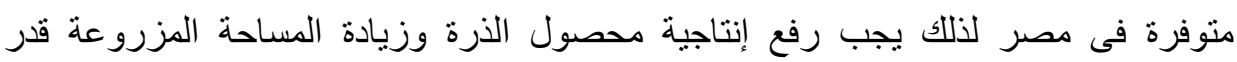
المستطاع لتغطية الإستهلاك المحلى.

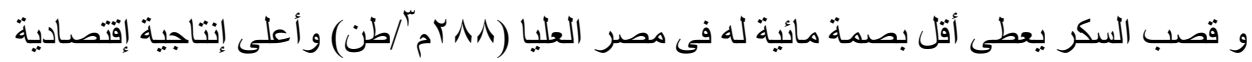

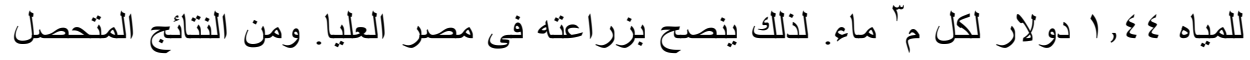

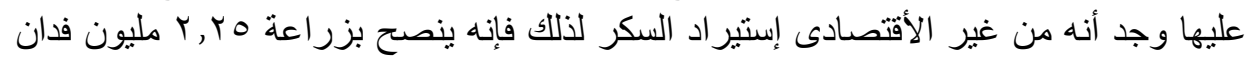

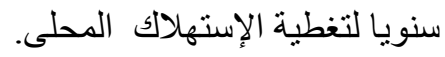

